\title{
KARAKTERISTIK DAN AKTIVITAS ANTIOKSIDAN RUMPUT LAUT Gracilaria sp. ASAL BANTEN
}

\author{
Sri Purwaningsih ${ }^{\star}$, Eka Deskawati
}

Departemen Teknologi Hasil Perairan, Fakultas Perikanan dan Ilmu Kelautan, Institut Pertanian Bogor Institut Pertanian Bogor, Kampus IPB Darmaga, Jalan Agatis, Bogor 16680 Jawa Barat

Telepon (0251) 8622909-8622906, Faks. (0251) 8622915

Diterima: 12 Oktober 2020/Disetujui: 15 Desember 2020

*Korespondensi: sripurwa65@gmail.com

Cara sitasi: Purwaningsih S, Deskawati E. 2020. Karakteristik dan aktivitas antioksidan rumput laut Gracilaria sp. asal Banten. Jurnal Pengolahan Hasil Perikanan Indonesia. 23(3): 503-512.

\begin{abstract}
ABSTRAK
Rumput laut Gracilaria sp. sering dimanfaatkan sebagai sumber agar-agar komersial. Penelitian ini bertujuan untuk menentukan karakteristik dari Gracilaria sp. sebagai bahan baku pangan fungsional. Metode ekstraksi pada penelitian ini yaitu maserasi tunggal menggunakan berbagai pelarut seperti: etanol, etil asetat, dan n-heksan, dengan perbandingan Gracilaria sp. dan pelarut yaitu 1:6. Parameter analisis terdiri atas proksimat, logam berat, rendemen, fitokimia, penentuan total fenol dan total flavonoid menggunakan metode spektrofotometer UV-Vis, serta aktivitas antioksidan menggunakan metode DPPH. Hasil penelitian menunjukkan kadar air 83,28\% (bb), protein 9,36\%, lemak 0,60\%, abu 24,83\% dan karbohidrat $11,05 \%$ (bk). Kadar logam berat $\mathrm{Hg}, \mathrm{Pb}, \mathrm{Cd}$ di bawah ambang batas dan tidak ditemukan logam berat As sesuai dengan SNI 2690:2015. Pengujian komponen bioaktif ekstrak etanol Gracilaria sp. secara kualitatif didapatkan alkaloid, fenol, saponin, flavonoid, triterpenoid. Kadar total flavonoid dan total fenol berturutturut sebesar 21,78 $\pm 0,32 \mathrm{mg}$ QE/g dan 124 $\pm 2,13 \mathrm{mg} \mathrm{GAE} / \mathrm{g}$. Perbedaan pelarut dalam ekstraksi berpengaruh nyata $(\alpha=0,05)$ terhadap aktivitas antioksidan, dengan aktivitas tertinggi adalah ekstrak etanol dengan nilai IC $_{50}$ sebesar 22,15 $\pm 1,63 \mu \mathrm{g} / \mathrm{mL}$ (sangat kuat). Hasil penelitian ini membuktikan bahwa Gracilaria sp. aman dan dapat digunakan sebagai bahan baku pangan fungsional.
\end{abstract}

Kata kunci: antioksidan, Gracilaria sp., komponen bioaktif, logam berat, proksimat

\section{Characteristics and Antioxidant Activities of Gracilaria sp. Seaweed from Banten}

\section{ABSTRACT}

The Gracilaria sp. seaweed is often used as a source of commercial agar, however in recent years the price of this seaweed has dropped dramatically. Red seaweed has many health benefits. This study was aimed to determine proximate contains, heavy metal, total phenol and total flavonoid, and antioxidant activity of the seaweed Gracilaria sp. Extraction using the maceration method with ethanol, ethyl acetate, and $\mathrm{n}$-hexane solvents with a ratio of 1:6 had a significant effect $(\alpha=0.05)$ on the antioxidant activity.The highest antioxidant activity was observed fromthe ethanolic extract with $\mathrm{IC}_{50}=22.15 \pm 1.63 \mu \mathrm{g} / \mathrm{mL}$ (very strong). Qualitative testing of the bioactive components of the ethanol extract of Gracilaria sp. found alkaloids, phenols, saponins, flavonoids, triterpenoids. Tests for total flavonoids and total phenols were carried out using a UV-Vis spectrophotometer obtaining $21.78 \pm 0.32 \mathrm{mg} \mathrm{QE} / \mathrm{g}$ and $124 \pm 2.13 \mathrm{mg} \mathrm{GAE} / \mathrm{g}$ respectively.

Keywords: antioxidant, bioactive compound, heavy metal, Gracilaria sp., proximate

\section{PENDAHULUAN}

Rumput laut cocok dijadikan bahan pangan serta bermanfaat untuk kesehatan karena mengandung serat, asam-asam amino, lemak yang rendah, karbohidrat, mineral, dan vitamin (Amaranggana dan Wathoni 2017). Kandungan serat dan bahan aktif polifenol yang terdapat pada rumput laut memiliki peranan penting terhadap respons glikemik dan pengaturan berat badan yang dapat menurunkan indeks glikemik (Hall et al. 2012). Kandungan agar-agar yang tinggi sangat bermanfaat untuk berbagai keperluan sehingga masyarakat dunia dapat mengonsumsi produk-produk hasil alam (back to nature) (Hasan et al. 2015). Salah 
satu rumput laut merah yang potensial adalah Gracilaria sp. Gracilaria sp. banyak digunakan sebagai sumber agar-agar komersial dan sebagai sumber polisakarida tersulfasi yang digunakan dalam industri farmasi dan bioteknologi (Coura et al. 2012).

Kesadaran masyarakat akan pentingnya hidup sehat, awet muda atau pencegahan penyakit degeneratif akibat radikal bebas semakin meningkat, salah satunya dengan mengonsumsi makanan yang kaya akan antioksidan. La Barre et al. (2010) menyatakan alga menyintesis berbagai senyawa yaitu antioksidan seperti polifenol, karotenoid, xantofil, klorofil, fukoidan, vitamin, asam lemak jenuh dan tak jenuh ganda, asam amino, acetogenins, alkaloid, terpenoid, senyawa terhalogenasi dan polisakarida misalnya agar, karagenan, proteoglikan, alginat, laminaran, rhamnan sulfat, dan galaktosil gliserol. Sanger et al. (2010) melaporkan bahwa ekstrak aseton G. salicornia memiliki kadar fikoeritrin sebesar $1,08 \pm 0,08 \mu \mathrm{g} / \mathrm{g}$ (berat kering) dan fukosantin yaitu $0,01 \pm 0,004 \mathrm{mg} / \mathrm{g}$. Alga merah merupakan sumber bahan baku antioksidan, adapun komponen antioksidan antara lain antheraxanthin (karotenoid), fikoeritrin (pikobilin), galaktan dan sulfat galaktan (Pereira et al. 2012). Tumbuhan air mampu menyerap logam berat sehingga terjadi akumulasi yang mengakibatkan kadar logam-logam tersebut lebih tinggi dibandingkan lingkungannya (Sudir et al. 2017). Penelitian ini bertujuan menentukan karakteristik dari rumput laut Gracilaria sp. yang berasal dari perairan Banten-Indonesia, meliputi kandungan kimia, komponen aktif, kadar logam berat, dan aktivitas antioksidan.

\section{BAHAN DAN METODE Bahan dan Alat}

Bahan baku yang digunakan yaitu rumput laut Gracilaria sp. dalam bentuk kering dan berasal dari daerah Kampung Berangbang, Desa Lontar, Kecamatan Tirtayasa Serang, Banten, Jawa Barat. Bahan kimia untuk analisis berupa etanol (Merck, Jerman), n-heksan (Merck, Jerman), etil asetat (Merck, Jerman), $\mathrm{H}_{3} \mathrm{BO}_{3}$ (Sigma-Aldrich, AS), $\mathrm{H}_{2} \mathrm{SO}_{4}$ (Merck, Jerman), $\mathrm{HCl}$ (Merck, Jerman), $\mathrm{CHCl}_{3}$ (SigmaAldrich, AS), asam asetat (Merck, Jerman),
$\mathrm{Mg}$ (Merck, Jerman), $\mathrm{FeCl}_{3}$ (Merck, Jerman). $\mathrm{HNO}_{3}$ (Merck, Germany), $\mathrm{NH}_{4} \mathrm{H}_{2} \mathrm{PO}_{4}$ (SigmaAldrich, AS), $\mathrm{NaOH}$ (Merck, Jerman), $\mathrm{NaBH}_{4}$ (Merck, Jerman), $\mathrm{HCl}$ (Merck, Jerman), 1,1-Difenil-2-2pikrilhidrazil (Sigma-Aldrich). asam askorbat (Merck, Jerman).

Alat yang digunakan adalah shaker (DLAB SK-0330 pro, China), alat-alat gelas (Pyrex, Jepang), tanur (Vulcan, AS), labu destruksi (Pyrex, Jepang), mikro pipet (Socorex, Swiss), AAS (Atomic Absorbtion Spectrofotometri) (Shimadzu AA-7000, Jepang), UV-Vis RS Spectrophotometer (UV-2500, Jepang)

\section{Metode Penelitian Preparasi bahan baku}

Rumput laut Gracilaria sp. yang digunakan dalam penelitian ini diambil dari tambak pada umur panen sekitar 50-60 hari. Pemanenan dilakukan dengan cara rumpun tanaman diangkat kedalam perahu dan diangkut ke darat. Gracilaria sp. dibersihkan dari kotoran/lumpur kemudian dijemur di bawah sinar matahari sampai kering. Rumput laut yang kering kemudian dilakukan analisis proksimat.

\section{Pembuatan Tepung Gracilaria sp.}

Pembuatan tepung mengacu pada penelitian Purwaningsih et al. (2020) dan Fauzi (2017), yaitu pencucian Gracilaria sp. dari kotoran, perendaman selama satu malam, pencucian, dan penggilingan. Tepung Gracilaria sp. kemudian dilakukan analisis proksimat.

\section{Ekstraksi Gracilaria sp.}

Ekstrasi Gracilaria sp. mengacu pada Julyasih et al. (2009) menggunakan metode maserasi tunggal dengan beberapa pelarutyaitu etanol, etil asetat dan n-hexan dengan perbandingan Gracilaria sp. dan ekstrak 1:6 selama $48 \mathrm{jam}$. Hasil maserasi disaring dengan kertas Whatman no 42 dan dipekatkan menggunakan rotary evaporator pada suhu $40 \quad{ }^{\circ} \mathrm{C}$ sampai terbentuk pasta. Ekstrak kemudian ditimbang dan dihitung rendemen dengan rumus sebagai berikut:

Rendemen $=\frac{\text { berat ekstrak }(\mathrm{g})}{\text { berat sampel }(\mathrm{g})} \times 100 \%$ 


\section{Analisis proksimat}

Analisis proksimat mengacu pada metode AOAC (2005) meliputi analisis kadar air, abu, protein, lemak, dan karbohidrat dengan metode by difference. Uji kadar air dengan metode oven, kadar abu dengan metode tanur, uji kadar protein menggunakan metode kjeldahl, uji kadar lemak menggunakan metode soxhlet, dan uji karbohidrat secara by difference.

\section{Analisis logam berat}

Pengujian logam berat dilakukan pada tepung dari rumput laut Gracilaria sp. Pengujian logam berat kadmium (Cd) dan timbel $(\mathrm{Pb})$ dalam sampel diukur dengan cara digesti kering (pengabuan) bedasarkan BSN (2011), sedangkan analisis logam berat merkuri $(\mathrm{Hg})$ mengacu pada metode BSN (2006) serta arsen mengacu pada metode BSN (1998).

\section{Analisis aktivitas antioksidan}

Aktivitas antioksidan dari tiga jenis ekstrak yaitu ekstrak etanol, n-heksan, dan etil asetat pada penelitian ini diukur menggunakan metode DPPH mengacu pada Molyneux (2004).

\section{Analisis fitokimia}

Analisis fitokimia yang dilakukan terhadap ekstrak Gracilaria sp. meliputi pemeriksaan senyawa alkaloid, flavonoid, saponin, tanin, fenol hidroquinon, dan steroid/triterpenoid mengacu pada Harborne (1987).

\section{a. Alkaloid}

Sebanyak $50 \mathrm{~g}$ sampel dilarutkan dalam asam sulfat $\left(\mathrm{H}_{2} \mathrm{SO}_{4}\right) 2 \mathrm{~N}$ sebanyak 2 tetes. Larutan sampel diletakkan pada plat tetes dan ditetesi pereaksi. Pengujian menggunakan tiga pereaksi alkaloid yaitu Dragendorff, Meyer, dan Wagner. Hasil uji positif apabila terbentuk endapan merah hingga jingga dengan pereaksi Dragendorff, endapan putih kekuningan dengan dengan pereaksi Meyer, dan endapan coklat dengan pereaksi Wagner.

\section{b. Flavonoid}

Sebanyak $50 \mathrm{mg}$ sampel ditambah dengan 0,05 mg serbuk $\mathrm{Mg}$ dan dilarutkan menggunakan 0,2 $\mathrm{mL}$ amil alkohol (campuran
$\mathrm{HCl} 37 \%$ dan etanol 95\% dengan volume yang sama) dan $4 \mathrm{~mL}$ alkohol $70 \%$. Hasil uji positif apabila terbentuk warna merah, kuning atau jingga pada lapisan amil alkohol.

\section{c. Fenol Hidrokuinon}

Sebanyak $50 \mathrm{mg}$ sampel dilarutkan dalam $0,25 \mathrm{~mL}$ etanol $70 \%$. Larutan ditambahkan $\mathrm{FeCl}_{3} 5 \%$ sebanyak 2 tetes. Hasil uji positif apabila terbentuk warna hijau atau hijau biru.

\section{d. Saponin}

Sampel sebanyak $50 \mathrm{~g}$ dalam tabung reaksi ditambahkan air panas $20 \mathrm{~mL}$ lalu dikocok. Hasil uji positif apabila busa yang terbentuk stabil selama 30 menit dan tidak hilang pada penambahan 1 tetes $\mathrm{HCl} 2 \mathrm{~N}$.

\section{e. Steroid/Terpenoid}

Sebanyak $50 \mathrm{mg}$ sampel ditambah dengan $2 \mathrm{~mL}$ kloroform kemudian ditetesi dengan anhidrida asam asetat sebanyak 5 tetes dan asam sulfat pekat $\left(\mathrm{H}_{2} \mathrm{SO}_{4}\right) 2 \mathrm{~N}$ sebanyak 3 tetes. Hasil uji positif ditunjukkan dengan terbentuknya larutan berwarna merah kecokelatan untuk petama kali yang kemudian berubah menjadi biru dan hijau. Warna biru pada larutan menandakan adanya kandungan steroid sedangkan warna merah kecokelatan menandakan adanya kandungan triterpenoid. f. Tanin

Sebanyak $50 \mathrm{mg}$ sampel ditambah dengan $20 \mathrm{~mL}$ air panas lalu disaring dan ditetesi $\mathrm{FeCl}_{3}$ $1 \%$ sebanyak 2 tetes. Hasil uji positif apabila larutan berwarna biru atau hijau kehitaman

\section{Analisis total fenol}

Kadar fenol pada ekstrak terpilih dari rumput laut Gracilaria sp. dilakukan dengan metode Wan-Ibrahim et al. (2010). Sebanyak $10 \mu \mathrm{L}$ larutan ekstrak konsentrasi $1 \mathrm{mg} /$ $\mathrm{mL}$ (pelarut etanol) dimasukkan ke dalam microplate yang berisi $160 \mu \mathrm{L}$ akuades, lalu ditambah $10 \mu \mathrm{L}$ reagen Folin-Ciocalteu 10\% dan $20 \mu \mathrm{L}$ larutan $\mathrm{Na} 2 \mathrm{CO} 3$ 10\%. Larutan diinkubasi selama 30 menit pada suhu ruang dan diukur absorbansinya menggunakan spektrofotometer pada panjang gelombang $750 \mathrm{~nm}$. Standar yang digunakan yaitu asam galat dengan berbagai konsentrasi $(20,40$, $60,80,100 \mu \mathrm{g} / \mathrm{mL}$ ). 


\section{Analisis total flavonoid}

Total flavonoid dari ekstrak terpilih dari rumput laut Gracilaria sp. dilakukan dengan mengacu pada Son et al. (2015). Sebanyak $10 \mu \mathrm{L}$ larutan ekstrak konsentrasi $1 \mathrm{mg} /$ $\mathrm{mL}$ (pelarut etanol) dimasukkan ke dalam microplate yang berisi $120 \mu \mathrm{L}$ akuades, lalu ditambah $10 \mu \mathrm{L}$ aluminium klorida 10\%, $10 \mu \mathrm{L}$ larutan asam asetat dan $60 \mu \mathrm{L}$ etanol. Larutan diinkubasi selama 30 menit pada suhu ruang dan diukur absorbansinya menggunakan spektrofotometer pada panjang gelombang $415 \mathrm{~nm}$. Standar yang digunakan yaitu kuersetin dengan berbagai konsentrasi $(100,150,200,250,300 \mu \mathrm{g} / \mathrm{mL})$.

\section{Analisis Data}

Penentuan ekstrak terbaik dilakukan Rancangan Acak Lengkap (RAL) dengan perlakuan jenis pelarut terhadap aktivitas antioksidan dari rumput laut Gracilaria sp. Semua perlakuan dilakukan sebanyak 3 kali ulangan. Analisis data menggunakan analisis ragam (ANOVA), bila hasil uji menunjukkan pengaruh nyata dilanjutkan dengan uji lanjut Duncan pada taraf kepercayaan 95\% (Mattjik dan Sumertajaya 2013).

\section{HASIL DAN PEMBAHASAN Kandungan Proksimat}

Hasil analisis proksimat dalam kondisi basah dan kering dalam bentuk tepung disajikan pada Table 1.

Kadar air tepung rumput laut akan menentukan daya awet, semakin tinggi kadar air maka daya awet dari tepung rumput laut semakin rendah. Hasil penelitian menunjukkan bahwa kadar air rumput laut dalam kondisi basah sangat tinggi, setelah menjadi tepung kadar air dari rumput laut tidak jauh berbeda dengan hasil penelitian Munandar et al. (2019) dan sesuai dengan SNI 2690:2015 yaitu maksimal 12\%.

Kadar protein rumput laut berbeda antara satu daerah dengan daerah lain, karena kadar protein dipengaruhi oleh habitatnya dan jenis rumput laut itu sendiri, serta umur dari rumput laut. Dari data terlihat bahwa kadar protein pada penelitian ini lebih tinggi dibanding kadar protein hasil penelitian Munandar et al. (2019). Meskipun dari perairan yang sama, kondisi perairan tempat tumbuhnya bibit rumput laut yang ditanam dapat mempengaruhi kandungan protein, misalnya unsur hara nitrat dan fosfat. Menurut Yudiati et al. (2020) apabila Gracilaria sp. kekurangan kedua senyawa tersebut, akan menyebabkan penurunan kandungan protein pada sel-sel rumput laut dan diikuti dengan degradasi berbagai komponen sel yang berkaitan dengan sintesa protein.

Kadar abu tepung rumput laut penelitian ini lebih rendah dibanding dengan rumput laut penelitian Munandar et al. (2019), hal ini dikerenakan rumput laut pada penelitian ini dicuci terlebih dulu sebelum digunakan. Kadar abu yang tinggi menunjukkan bahwa tingginya kandungan mineral dalam bahan.

\section{Kadar Logam Berat}

Terdapat empat jenis logam berat yang diuji sesuai yang disyaratkan dalam SNI 2690 : 2015 tentang rumput laut kering. Abernethy et al. (2010) menjelaskan bahwa cemaran logam berat terutama timbel $(\mathrm{Pb})$, kadmium (Cd), merkuri (Hg), dan arsen

Table 1 Result of chemical content from Gracilaria sp. seaweed

\begin{tabular}{lrrr}
\hline \multirow{2}{*}{ Parameter } & \multicolumn{3}{c}{ Value (\%) } \\
\cline { 2 - 4 } & Gracilaria sp. & $\begin{array}{c}\text { Gracilaria sp. } \\
\text { flour }\end{array}$ & $\begin{array}{c}\text { Gracilaria } \\
\text { sp. flour }\end{array}$ \\
\hline Moisture & $83.28+3.25^{*}$ & $10.72+0.85$ & 11.83 \\
Protein & $9.36+0.50$ & $12.78+1.28$ & 8.77 \\
Lipid & $0.60+0.003$ & $1.18+0.16$ & 0.32 \\
Ash & $24.83+0.83$ & $10.19+0.75$ & 15.08 \\
Carbohydrate (by difference) & $11.05+0.24$ & $65.13+1.42$ & 64.00 \\
\hline Note: ${ }^{*}$ )wet basis, dw (dry weight); ${ }^{* *}$ )Munandar et al. $(2019)$ &
\end{tabular}


Table 2 Heavy metal content from Gracilaria sp. seaweed

\begin{tabular}{lccr}
\hline \multirow{2}{*}{ Heavy Metals } & \multicolumn{2}{c}{ Value $(\mathrm{ppm})$} & \multirow{2}{*}{$\begin{array}{c}\text { Standard } \\
(\mathrm{ppm})\end{array}$} \\
\cline { 2 - 4 } & Banten & Bekasi $^{* *}$ & 0.5 \\
$\mathrm{Hg}$ & 0.011 & - & 0.3 \\
$\mathrm{~Pb}(<0.005)$ & 0.001 & $0.515 \pm 0.040$ & 0.1 \\
$\mathrm{Cd}(<0.005)$ & 0.010 & $0.121 \pm 0.003$ & 1.0 \\
$\mathrm{As}(<0.002)$ & 0.000 & - & (dry seaweed)
\end{tabular}

(As) perlu diawasi karena efek bahaya yang ditimbulkan seperti gangguan ginjal, sifat neurotoksin yang mengganggu perkembangan otak dan gangguan sistem saraf, efek kardiovaskular, imunotoksisitas dan karsinogenisitas. Hasil penelitian (Table 2) menunjukkan bahwa kadar logam berat yang terdapat dalam bahan memenuhi standar BSN (2015).

Kadar logam berat dalam rumput laut sangat tergantung dari habitat di mana dia tumbuh atau lokasi sangat menentukan. Hasil penelitian menunjukkan bahwa rumput laut Gracilaria sp. yang berasal dari Banten memenuhi standar SNI sedangkan rumput laut Gracilaria sp. dari Bekasi hasil penelitian Afiah et al. (2019), menunjukkan bahwa kadar logam berat $\mathrm{Cd}$ dan $\mathrm{Pb}$ melebihi standar yang ditentukan. Hasil penelitian kadar logam berat dari rumput laut oleh Purwaningsih et al. (2020) menunjukkan bahwa kadar logam berat Gracilaria sp. dari Kabupaten Bekasi masih memenuhi standar yang ditetapkan BSN (2015). Kandungan logam berat pada rumput laut yang dibudidayakan di muara perkotaan memang harus dipantau, terutama rumput laut yang dibudidayakan di lokasi sekitar industri dengan pengelolaan limbah yang buruk berdampak pada tingkat logam berat yang lebih tinggi.

\section{Rendemen Ekstrak}

Ekstraksi yang digunakan pada penelitian adalah ekstraksi tunggal dengan metode maserasi menggunakan tiga jenis pelarut dengan tingkat kepolaran yang berbeda yaitu n-heksana (nonpolar), etil asetat (semi polar), dan etanol (polar) dan dilakukan selama 48 jam. Penelitian (Hardiningtyas 2012) menjelaskan semakin lama waktu proses ekstraksi maka kesempatan bersentuhan antara bahan dan pelarut semakin besar sehingga komponen aktif dalam bahan dapat terlarut dengan baik. Rendemen hasil ekstraksi dengan jenis pelarut yang berbeda disajikan dalam Table 3 .

Hasil ekstraksi memperlihatkan pelarut etanol memiliki rendemen paling banyak yaitu 2,13 $\pm 0,66$. Nilai rendemen yang tinggi menggunakan pelarut etanol diduga kemampuan pelarut etanol dalam melarutkan hampir semua komponen aktif. Zhang et al. (2007) menyatakan bahwa prinsip umum ekstraksi adalah "like dissolves like", hal ini menunjukkan bahwa suatu pelarut hanya mengekstrak senyawa kimia yang memiliki polaritas yang sama. Jumlah rendemen ekstrak bergantung pada kondisi alamiah senyawa, metode ekstraksi, ukuran partikel sampel, kondisi dan waktu ekstraksi, serta perbandingan sampel dengan pelarut (Harborne 1987)

Table 3 Yield of Gracilaria sp. extract

\begin{tabular}{lcrr}
\hline \multicolumn{1}{c}{ Solvent } & \% Yield & $\begin{array}{l}\text { Phenol total } \\
(\mathrm{mg} \mathrm{GAE} / \mathrm{g})\end{array}$ & \multicolumn{1}{c}{$\begin{array}{l}\text { Flavonoids } \\
(\mathrm{mg} \mathrm{QE} / \mathrm{g})\end{array}$} \\
\hline Ethanol & $2.13 \pm 0.66$ & $124 \pm 2.13$ & $21.78 \pm 0.32$ \\
Ethyl acetate & $1.22 \pm 0.42$ & $28 \pm 1.42$ & $25.23 \pm 0.46$ \\
n-hexan & $1.07 \pm 0.83$ & $64 \pm 1.63$ & $9.78 \pm 0.22$ \\
\hline
\end{tabular}


Table 4 Active components from Gracilaria sp. seaweed

\begin{tabular}{lccc}
\hline \multirow{2}{*}{ Bioactive Compound } & \multicolumn{3}{c}{ Results } \\
\cline { 2 - 4 } & $\begin{array}{c}\text { Ethanol } \\
\text { extract }\end{array}$ & $\begin{array}{c}\text { N-Hexane } \\
\text { extract }\end{array}$ & $\begin{array}{c}\text { Ethyl acetate } \\
\text { extract }\end{array}$ \\
\hline Alkaloid & + & + & - \\
$\quad$ Mayer & + & + & - \\
$\quad$ Wagner & + & + & - \\
$\quad$ Dragendrof & + & + & - \\
Phenol hydroquinone & - & - & - \\
Tannins & + & + & - \\
Saponins & + & + & + \\
Flavonoids & - & - & - \\
Steroids & + & - & + \\
Triterpenoids & & & \\
\hline
\end{tabular}

\section{Kandungan Komponen Bioaktif}

Pengujian terhadap komponen bioaktif dilakukan pada tiga jenis ekstrak rumput laut Gracilaria sp. yaitu etanol, nheksan, dan etil asetat. Hasil uji terhadap komponen bioaktif dari ekstrak rumput laut Gracilaria sp. disajikan pada Table 4.

Hasil uji memperlihatkan ekstrak etanol dari rumput laut Gracilaria sp. memiliki komponen bioaktif paling banyak yaitu alkaloid, fenol, saponin, flavonoid, triterpenoid. Etanol dapat melarutkan senyawa flavonoid maupun saponin yang mempunyai bagian yang bersifat polar maupun nonpolar dengan bagian yang hampir sama. Terpenoid memiliki bagian polar dan nonpolar, tetapi bagian nonpolar pada terpenoid jauh lebih banyak dibandingkan bagian polar sehingga terpenoid cenderung lebih mudah larut dalam pelarut nonpolar. Septiana dan Asnani (2012) menjelaskan bahwa senyawa seperti tanin cenderung polar sehingga ekstraksi dengan pelarut polar, seperti metanol dan etanol akan mengestrak tanin secara optimal.

Beberapa komponen bioaktif seperti fenol hidrokuinon, saponin, flavonoid, steroid dan tannin merupakan antioksidan. Menurut Mahardika dan Roanisca (2018) bahwa hidrogen radikal pada senyawa fenol hidrokuinon mudah didonorkan, sehingga senyawa ini merupakan antioksidan yang baik. Saponin terdeteksi pada ekstrak etanol karena senyawa glikosida tidak larut dalam pelarut nonpolar. Saponin merupakan glikosida yang memiliki aglikon berupa steroid dan triterpenoid, senyawa ini aktif pada permukaan dan bersifat seperti sabun. Xiong et al. (2010) menjelaskan bahwa saponin mempunyai aktivitas sebagai antioksidan menyumbangkan hidrogen untuk menghentikan reaksi pada radikal. Flavonoid masuk dalam golongan senyawa fenolik dan berperan sebagai antioksidan dengan mendonorkan atom hidrogen atau mengkelat logam, dalam bentuk bebas yang disebut aglikon atau bentuk glukosida. Redha (2010) menjelaskan bahwa flavonoid merupakan salah satu senyawa metabolit sekunder yang paling banyak ditemukan di dalam jaringan tanaman. Menurut Topcu et al. (2007) mekanisme antioksidan dari steroid adalah dengan cara menangkap/ scavenging spesies reaktif, seperti superoksida, dan mengkelat logam $\left(\mathrm{Fe}^{2+}\right.$ dan $\left.\mathrm{Cu}^{2+}\right)$. Malangngi et al. (2012) melaporkan bahwa tanin memiliki peranan biologis kompleks mulai dari pengendap protein hingga pengkhelat logam. Tanin dapat berfungsi sebagai antioksidan biologis. Kandungan tanin yang tinggi maka semakin besar aktivitas antioksidannya karena tanin tersusun dari senyawa-senyawa polifenol yang memiliki aktivitas penangkap radikal bebas. 


\section{Kandungan Total Fenol}

Hasil pengujian total fenol secara kualitatif ekstrak ketiga pelarut disajikan pada Table 3.

Hasil penelitian menunjukkan bahwa total fenol dipengaruhi oleh jenis pelarut yang digunakan, dan yang tertinggi yaitu ekstrak etanol sebesar 124 $\pm 2,13$. Bangol et al. (2014) menyatakan bahwa sebagian besar senyawa fenolik bersifat polar. Matanjun et al. (2008) menyatakan bahwa rumput laut memiliki senyawa fenolik/total fenol yang berbeda-beda tergantung spesies rumput laut, jenis pelarut dan metode ekstraksi. Rajauria et al. (2016) menyatakan bahwa kandungan polifenol dari rumput laut bervariasi menurut jenis spesies, musim, umur panen, waktu panen, dan letak geografis. Hasil penelitian lain yang dilakukan oleh Yanuarti (2017) menunjukkan bahwa total fenol dari rumput laut $E$. cottonii yang diekstrak dengan metanol lebih tinggi $(141 \pm 3,33 \mathrm{mg}$ GAE/g) dibandingkan etil asetat $(134,33 \pm 3,33 \mathrm{mg}$ GAE/g). Chakraboty et al. (2013) menjelaskan total fenol yang ditemukan pada ekstrak metanol $H$. musciformid dan $H$. valentia berturut-turut $6,90 \mathrm{mg} \mathrm{GAE} / \mathrm{g}$ dan 9,80 mg $\mathrm{GAE} / \mathrm{g}$.

\section{Kandungan Total Flavonoid}

Hasil pengujian total flavonoid secara kualitatif ekstrak ketiga pelarut disajikan pada Table 3.

Hasil penelitian menunjukkan bahwa total flavonoid dari ekstrak etil asetat dari rumput laut Gracilaria sp. mempunyai nilai tertinggi sebesar 25,23 $\pm 0,46 \mathrm{mg}$ QE/g diikuti etanol. Hal ini dipengaruhi oleh sifat kelarutan dari senyawa flavonoid dari rumput laut. Menurut Pramudia (2008) flavonoid yang berikatan dengan gula cenderung larut dalam air (polar), sedangkan aglikon yang kurang polar misalnya isoflavon, flavonon, flavon, dan flavonol cenderung lebih mudah larut dalam pelarut semi polar. Flavonoid merupakan salah satu antioksidan alami yang memiliki fungsi menghambat oksidasi low density lipoprotein (LDL) yang merupakan pemicu terjadinya penyempitan pada pembuluh darah. Zhu et al. (2000) mengemukakan bahwa senyawa flavonoid alami antara lain kaempferol, miricetin, morin, dan quercetin memiliki aktivitas perlindungan dengan menurunkan kandungan $\alpha$-tokoferol dalam LDL. Yanuarti et al. 2017 menunjukkan bahwa total flavonoid rumput laut E. cottonii yang diekstrak dengan etil asetat lebih besar $(35,17 \pm 1,00 \mathrm{mg} \mathrm{QE} / \mathrm{g})$ dibandingkan dengan metanol (17,78 $\pm 0,31 \mathrm{mg} \quad \mathrm{QE} / \mathrm{g})$. Meenakshi et al. (2009) melaporkan total flavonoid pada ekstrak metanol S. wightii sebanyak 2,02 mg QE/g.

\section{Aktivitas Antioksidan}

Hasil pengujian total fenol secara kualitatif ekstrak ketiga pelarut disajikan pada Table 5.

Kekuatan aktivitas antioksidan suatu ekstrak akan digolongkan berdasarkan batasan kemampuan dalam menangkap radikal bebas. Molyneux (2004) menggolongkan kekuatan aktivitas antioksidan sebagai berikut : suatu senyawa dikatakan memiliki aktivitas antioksidan sangat kuat bila mempunyai nilai $\mathrm{IC}_{50}$ kurang dari $50 \mu \mathrm{g} / \mathrm{mL}$, kuat $50-100 \mu \mathrm{g} / \mathrm{mL}$, sedang 101-150 $\mu \mathrm{g} / \mathrm{mL}$ dan lemah 150-200 $\mu \mathrm{g} /$ $\mathrm{mL}$.

Hasil penelitian menunjukkan bahwa jenis pelarut memberikan pengaruh pada nilai $\mathrm{IC}_{50} /$ aktivitas antioksidan. Hasil uji lanjut menunjukkan bahwa masing-masing ekstrak mempunyai kekuatan aktivitas yang berbeda-

Table 5 Antioxidant activity of Gracilaria sp. seaweed

\begin{tabular}{lrl}
\hline \multicolumn{1}{c}{ Extract } & $\mathrm{IC}_{50}$ Value $(\mu \mathrm{g} / \mathrm{mL})$ & \multicolumn{1}{c}{ Information } \\
\hline Ascorbic acid & $6.02 \pm 0.02$ & Positive control \\
Ethanol & $22.15 \pm 1.63^{\mathrm{a}}$ & Very strong \\
Ethyl acetate & $72.77 \pm 2.59^{\mathrm{b}}$ & Strong \\
n-hexane & $109.12 \pm 2.41^{\mathrm{c}}$ & Moderate \\
\hline Note: very strong $=\mathrm{IC}_{50}$ value $<50 \mu \mathrm{g} / \mathrm{mL}$, strong $=50-100 \mu \mathrm{g} / \mathrm{mL}$, \\
\multicolumn{2}{c}{ moderate $=101-150 \mu \mathrm{g} / \mathrm{mL}$, weak $=150-200 \mu \mathrm{g} / \mathrm{mL}$}
\end{tabular}


beda, dan aktivitas terbaik adalah dari ekstrak etanol. Hasil penelitian menunjukkan bahwa aktivitas antioksidan yang paling baik dan tergolong aktivitas sangat kuat terdapat pada ekstrak etanol Gracilaria sp. Hal ini sesuai dengan kandungan komponen bioaktifnya pada penjelasan sebelumnya, yaitu ekstrak etanol mengandung alkaloid, fenol, saponin, flavonoid, triterpenoid yang dapat berfungsi sebagai antioksidan. Selain itu total fenol dan total flavonoid pada ekstrak etanol juga tinggi yaitu sebesar $124 \pm 2,13 \mathrm{mg}$ GAE/g dan $21,78 \pm 0,32 \mathrm{mg}$ QE/g. Penggunaan asam askorbat atau vitamin $\mathrm{C}$ sebagai pembanding pada pengukuran aktivitas antioksidan karena asam askorbat merupakan antioksidan yang dikonsumsi masyarakat dan juga terdapat dalam bahan makanan. Penelitian lain yang dilakukan oleh Yanuarti et al. (2017) tentang aktivitas antioksidan rumput laut menunjukkan bahwa ekstrak metanol T. conoides mempunyai nilai $\mathrm{IC}_{50}$ sebesar $15,14 \pm 9,76 \mu \mathrm{g} / \mathrm{mL}$ dan ekstrak etil asetat dari T. conoides nilainya sebesar 193,76 $\pm 3,30 \mu \mathrm{g} / \mathrm{mL}$, sedangkan ekstrak metanol dari rumput laut $E$. cottonii mempunyai nilai $\mathrm{IC}_{50}$ sebesar $23,15 \pm 1,49 \mu \mathrm{g} / \mathrm{mL}$ dan ekstrak etil asetat nilainya sebesar 594,68 $\pm 1,14 \mu \mathrm{g} /$ $\mathrm{mL}$. Suryaningrum et al. (2006) menyatakan bahwa aktivitas antioksidan dari rumput laut E. cottonii sangat kuat dengan nilai $\mathrm{IC}_{50}$ sebesar 45,6 $\mu \mathrm{g} / \mathrm{mL}$, sedangkan menurut Nurjanah et al. (2015) sebesar 105,04 $\mu \mathrm{g} / \mathrm{mL}$, dan menurut Maharany et al. (2017) sebesar $106,021 \mu \mathrm{g} / \mathrm{mL}$.

\section{KESIMPULAN}

Rumput laut Gracilaria sp. mengandung kadar proksimat dan kadar logam berat yang memenuhi standar SNI. Ekstrak etanol dari rumput laut Gracilaria sp. mempunyai aktivitas antioksidan yang paling baik dan tergolong aktivitas sangat kuat (nilai $\mathrm{IC}_{50}=22,15 \pm 1,63$ $\mu \mathrm{g} / \mathrm{mL}$ ). Kandungan komponen bioaktif dari ektrak etanol Gracilaria sp. adalah alkaloid, fenol, saponin, flavonoid, triterpenoid. Total flavonoid dari ekstrak etanol Gracilaria sp. sebesar 21,78 $\pm 0,32 \mathrm{mg} \mathrm{QE} / \mathrm{g}$, sedangkan total fenol sebesar 124 $\pm 2,13 \mathrm{mg} \mathrm{GAE} / \mathrm{g}$.

\section{DAFTAR PUSTAKA}

Afiah RN , Supartono W , Suwondo E. 2019. Potential of heavy metal contamination in cultivated red seaweed (Gracilaria sp. and Eucheuma cottonii) from coastal area of Java, Indonesia. IOP Conf. Series: Earth and Environmental Science 365 (2019) 012024.

Amaranggana L, Wathoni N. 2017. Manfaat alga merah (Rhodopyta) sebagai sumber obat dari bahan alam. Majalah Farmasetika. 2(1): 16-19.

Bangol E, Momuat LI, Abidjulu J. 2014. Aktivitas antioksidan ekstrak etanol dan $\mathrm{n}$-heksan dari daun rumput santa maria (Artemisia vulgaris L.) pada minyak ikan. Jurnal Ilmiah Sains. 14(2): 129-135..

[AOAC] Association of Official Analytical Chemyst. 2005. Official Method of Analysis (18 Edn). Arlington, Virginia, USA : Published by The Association of Official Analytical Chemist. Inc.

[BSN] Badan Standardisasi Nasional. 1998. Cara uji cemaran arsen dalam makanan: SNI 01- 4866-1998. Jakarta: Badan Standardisasi Nasional.

[BSN] Badan Standardisasi Nasional. 2006. Penentuan Kadar Logam Berat Merkuri (Hg) pada Produk Perikanan: SNI 012354.6-2006. Jakarta: Badan Standardisasi Nasional.

[BSN] Badan Standardisasi Nasional. 2011. Cara uji kimia Bagian 5: Penentuan kadar logam berat timbal $(\mathrm{Pb})$ dan kadmium (Cd) pada produk perikanan: SNI 2354.52011. Jakarta: Badan Standardisasi Nasional.

[BSN] Badan Standardisasi Nasional. 2015. Rumput laut kering: SNI 2690:2015. Jakarta: Badan Standarisasi Nasional.

Chakraborty K dan Joseph D. 2016. Antioxidant potential and phenolic compounds ofbrown seaweeds Turbinaria conoides and Turbinaria ornata (class: phaeophyceae). Journal of Aquatic Food Product Technology. 25(8):1249-1265

Coura CO, de Araújo IWF, Vanderlei ESO, Rodrigues JAG, Quinderé ALG, Fontes BP. et al. (2012). Antinociceptive and anti-inflammatory activities of sulphated polysaccharides from the red seaweed 
Gracilaria cornea. Basic and Clinical Pharmacology and Toxicology. 110(4): 335-341.

Fauzi, A. 2017. Karakteristik Beras Tiruan Dengan Penambahan Rumput Laut dan Agar-agar [skripsi]. Bogor (ID): Institut Pertanian Bogor.

Hall AC, Fairclough AC, Mahadevan K, Paxman JR. 2012. Ascophyllum nodosum enriched bread reduces subsequent energy intake with no effect on postprandial glucose and cholesterol in healthy, overweight males. Journal Appetite. 58: 379-386.

Harborne JB. 1987. Metode Fitokimia. Bandung : Penerbit ITB.

Hardiningtyas SD, Purwaningsih P, Handharyani E. 2014. Aktivitas antioksidan dan efek hepatoprotektif daun bakau api-api Putih. Jurnal Pengolahan Hasil Perikanan Indonesia. 17(1): 80-91.

Hasan MR, Rejeki S, Wisnu R. 2015. Pengaruh bobot awal yang berbeda terhadap pertumbuhan Gracilaria sp. yang dibudidayakan dengan metode longline di perairan tambak terabrasi Desa Kaliwlingi Kabupaten Brebes. Journal of Aquaculture Management and Technology. 4(2): 92-99.

Julyasih KSM, Wirawan IGP, Harijani WS, Widajati W. 2009. Aktivitas antioksidan beberapa jenis rumput laut (seaweeds) komersial di Bali. Seminar Nasional Akselerasi Pengembangan Teknologi Pertanian dalam Mendukung Revitalisasi Pertanian; 2009 Des 2; Surabaya, Indonesia, Surabaya (ID): Universitas Pembangunan Nasional Veteran. hlm 1-8.

La Barre S, Potin P, Leblanc C, Delage L. 2010. The halogenated metabolism of brown algae (Phaeophyta), its biological importance and its environmental significance. Marine Drugs. 8: 988-1010.

Maharany F, Nurjanah, Suwandi R, Anwar E, Hidayat T. 2017. Kandungan senyawa bioaktif rumput laut Padina australis dan Eucheuma cottonii sebagai bahan baku krim tabir surya. Jurnal Pengolahan Hasil Perikanan Indonesia. 20(1): 11-18.

Mahardika RG, Roanisca O. 2018. Aktivitas antioksidan dan fitokimia dari ekstrak etil asetat pucuk idat (Cratoxylum glaucum). Indonesian Journal of Chemical Research. 5(2): 69-74.

Malangngi LP, Meiske SS, Jessy JEP. 2012. Penentuan kandungan tanin dan uji aktivitas antioksidan ekstrak biji buah alpukat (Persea americana Mill.). Jurnal MIPA UNSRAT. 1(1): 5-10.

Matanjun P, Mohamed S, Mustapha NM, Muhammad K, Ming CH. 2008 Antioxidant activities and phenolic content of eight species of seaweed from North Borneo. Journal Applied Phycology. 20: $367-373$.

Mattjik AA, Sumertajaya M. 2013. Perancangan Percobaan dengan Aplikasi SAS dan Minitab. Bogor (ID): IPB Press.

Meenakshi SDM, Gnanambigai ST, Mozhi M, Arumugam T, Balasubramanian. 2009. Total flavonoid and in vitro antioxidant activity of two seaweed of rameshwaram coast. Global Journal of Pharmacology. 3(2): 59-62.

Molyneux P. 2004. The use of the stable free radikal diphenyl picrylhydrazyl (DPPH) for estimating antioxidant activity. Journal Science of Technology.26(2): 211-219.

Munandar A, Surilayani D, Haryati S, Sumantri MH, Aditia RP, Pratama G. 2019. Characterization flour of two seaweeds (Gracilaria spp. and Kappaphycus alvarezii) for reducing consumption of wheat flour in Indonesia. IOP Conf. Series: Earth and Environmental Science . 383 (2019) 012009.

Nurjanah, Nurilmala N, Anwar E, Luthfiyana N, Hidayat T. 2017. Identification of bioactive compounds of seaweed Sargassum sp. and Eucheuma cottonii Doty as a raw sunscreen cream. Proceedings of the Pakistan Academy of Sciences. 54(4): 311-318.

Pereira DC, Trigueiro TG, Colepicolo P, Marinho-soriano E. 2012. Seasonal changes in the pigment composition of natural population of Gracilaria dumingensis (Graciliares. Rhodophyta). Brazillians Journal of Pharmacognosy. 22:874-880. 
Purwaningsih S, Santoso J, Handharyani E, Setiawati NP, Deskawati E. 2020. Artificial rice from Gracilaria sp. as functional food to prevent diabetes. IOP Conf. Series: Earth and Environmental Science 414 (2020) 012017.

Rajauria G, Foley B, Abu-Ghannam N. 2016. Identification and characterization ophenolic antioxidant compounds from brown irish seaweed Himanthalia elongata using LC-DAD-ESI-MS/MS. Journal Innovative Food Science and Emerging Technologies. 37:261-268.

Redha A. 2010. Flavonoid: Struktur, sifat antioksidan dan peranannya dalam system biologis. Jurnal Berlian. 9 (2): 196202.

Sanger G. 2010. Kandungan fosfor minuman sari rumput laut (Eucheuma cottonii). Pacific Journal. 1(5): 792-795.

Septiana AT, Asnani A. 2012. Kajian sifat fisikokimia ekstrak rumput laut coklat Sargassum duplicatum menggunakan berbagai pelarut dan metode ekstraksi, Agrointek. 6 (1:22-28.

Son YR, Choi EH, Kim GT, Park TS, Shim SM. 2015. Bioefficacy of graviola leaf extracts in scavenging free radicals and upregulating antioxidant genes. Journal Food and Fungtion Royal Society of Chemistry. 7(2): 61-71.

Sudir S, Tumaruk Y, Taebe B, Naid T. 2017. Analisis kandungan logam berat As, $\mathrm{Cd}$ dan $\mathrm{Pb}$ pada Eucheuma cottonii dari Perairan Takalar serta analisis maximum tolerable intake pada manusia. Majalah Farmasi Dan Farmakologi. 21(3): 63-66.

Suryaningrum TD, Wikanta T, Kristiana $\mathrm{H}$. 2006. Uji aktivitas senyawa antioksidan dari rumput laut Halymenia harveyana dan Eucheuma cottonii. Jurnal Pascapanen dan Bioteknologi Kelautan dan Perikanan. 1(1): 51-63.

Topcu G, Ertas A, Kolak U, Ozturk M, Ulubelen A. (2007). Antioxidant activity tests on novel triterpenoids from Salvia macrochlamys. Archive for Organic Chemistry. 7: 195-208.

Wan-Ibrahim WI, Sidik K, Kuppusamy UR. 2010. A high antioxidant level in edible plants is associated with genotoxic properties. Food Chemistry. 122: 11391144.

Xiong Y, Yuan C, Chen R, Dawson TM, Dawson VL. 2010. Preparation and biological activity saponin Ophiogon japonicas. African Journal of Pharmacy and Pharmacology. 6 (2): 1964-1970.

Yanuarti R. 2017. Karakteristik bubur rumput laut Turbinaria conoides dan Eucheuma cottonii sebagai bahan baku krim tabir surya [tesis]. Bogor (ID): Institut Pertanian Bogor.

Yudiati E, Ridho A, Nugroho AA, Sedjati S, Maslukah L. 2020. Analisis kandungan agar, pigmen dan proksimat rumput laut Gracilaria sp. pada reservoir dan biofilter tambak udang Litopenaeus vannamei. Buletin Oseanografi Marina. 9(2): 133140.

Zhang ZS, Li D, Wang LJ, Ozkan N, Chen XD, Mao ZH, Yang HZ. 2007. Optimisation of ethanol-water extraction of lignans from flaxseed. Journal of Separation and Purification Technology. 57: 17-24

Zhu, Yan Q, Huang Y, Chen ZY. 2000. Insteractions between falvonoids and a-tocopherol in human low density lipoprotein. The Journal of Nutritional Biochemistry. 11 (1): 14-21. 